\title{
ІДЕЇ НАЦІОНАЛЬНОЇ ГРОМАДЯНСЬКОЇ РЕЛІГІЇ У ТВОРАХ ДІЯЧІВ УКРАЇНСЬКОГО КУЛЬТУРНОГО ВІДРОДЖЕННЯ КІНЦЯ XVI - ПОЧАТКУ ХVII СТ.
}

У науковій літературі немає загальновизнаного поняття громадянська релігія. У нашому розумінні, громадянська релігія - це такий суспільно-культурний феномен, в якому крізь призму своєрідної релігійної мови і специфічних практик обтрунтовується конечність постання і утвердження національної держави, яка виникає з потреби спільноти знаходити сакральне у трансиендентному, укоріненому в історію територій, чину. Можна сказати й так: громадянська релігія - це сприйняття нацією свого буття як богоданого, наперед визначеного, а отже, й виправданого, належного, неминучого, в якому певні соціально-політичні настанови набувають форм релігійних міфів, легенд тощо.

Досліджуваний феномен може існувати у двох формах: у зазначеній, коли йдеться про націю, що здобула і утверджує свою державність, і у формі національної громадянської релігії, за умов, коли нація веде боротьбу за виборення своєї держави.

Національна громадянська релігія, за умов, коли спільнота бореться за поновлення своєї державності, постає як сакральний вимір прагнення нації до відновлення і утвердження державності, сприйняття спільнотою своєї дієвості як наперед визначеної, в якій певні соціально-політичні настанови переплітаються з релігійними міфами, легендами, обрядами, практиками. Але таку релігію не можна ототожнювати ні з етнічними релігіями у прийнятому в науковій літературі значенні, ні 3 національною вірою як іншим означенням громадянської релігії, ні з етнічною (народною) громадянською релігією.

У науковій літературі відсутні розвідки, які б висвітлювали ідею національної громадянської релігії у творах діячів першого українського культурного відродження. Це i зумовило нагальність даного дослідження. Тому мета пропонованої статті вбачається у філософському і релігієзнавчому аналізі спадщини корифеїв українського відродження, а завдання полягає в окресленні ідей 
національної громадянської релігії цього періоду.

У XV-XVIII ст. майже в усій Європі відбувався процес формування націй, становлення національних держав, церков, культур. 3 XVI ст. аналогічні процеси розгортаються і в Україні. «Тут триває творення етнічної спільноти, яка підіймається над регіонами й діалектами і засвідчує своє існування інтенсивною розбудовою єдиного простору культури. Ця спільнота, - наголошує В.Нічик, - розуміється тогочасними авторами як така, що має єдине генетичне походження, історію, віру, мову, звичаї, казки й легенди різних розгалужень народу, який віддавна жив на одних і тих самих землях, мав у минулому могутню державу й називався Руссю» $[5,96]$. Наступає період культурно-національного відродження - друга половина XVI - перша половина XVII ст.

Правда, дослідники наголошують на неоднозначності вживаних у тодішній літературі понять «Русь», «руський народ». Ми поділяємо думку тих дослідників, які вважають, що якщо в соціальному розумінні українська шляхта відділяла себе від основної маси тогочасного населення України - посполитого «народу руського», то в національному плані панівна соціальна верства України відносила себе до «руського народу». «Відповідно до тогочасних історичних реалій, - наголошує П.Сас, - під «національним», крім віросповідання, розуміємо об'єднувальний психологічно та економічно фактор території проживання, спільність мови, звичаїв обрядів, ментальності, а також характерне для «теоретичного» типу свідомості осмислення спільності походження, історичної долі і вітчизни. Поняття «руський народ» у значенні політичної категорії було найуживанішим ідеологічним кліше в політичному лексиконі і зводилося переважно до значення широкої віросповідної спільноти, що заселяла українські і білоруські землі» [6, 485].

Релігійно-національне і культурне відродження другої половина XVI - першої половини XVII ст. обмежується двома надзвичайно важливими подіями в історії України. 1569 р. - Люблінська унія, за якою основна частина українських земель включалася до складу шляхетської Речі Посполитої. 1648 р. - початок українськопольської війни і поєднаного з нею соціально-політичного руху, що вже в ході першого етапу завершився утворенням Української козацької держави.

Період, що розглядається, дослідники поділяють на кілька етапів, найважливіший з яких охоплює приблизно останні два десяти- 
річчя XVI ст. і перші два десятиріччя XVII ст. «Це час могутніх козацьких повстань, які показали сучасникам впливовість і державотворчі можливості української козаччини, час особливої боротьби козаків як захисників південних степових кордонів України, зазначав Я. Ісаєвич, - і одночасно це доба важливих реформ релігійного життя, формування таких нових громадських структур, як братства, виникнення нових типів навчальних закладів, пожвавлення літературного життя, нових культурно-релігійних ініціатив представників різних конфесій, в тому числі православних, католиків, протестантів. Сформований у ті роки союз православних церковних і культурно-освітніх діячів 3 політичним проводом козаччини зробив можливим такий важливий успіх, як відновлення в 1620 р. православної ієрархії всупереч волі польського уряду і всіх панівних структур тодішньої польсько-шляхетської держави. Рух, що почався як культурно-освітній і релігійно-реформаційний набрав значною мірою політичного характеру» [3, 482].

Оскільки означений рух набуває політичного характеру, оскільки на українському небосхилі, образно висловлюючись, засяяла зірка державотворення, то цілком природно, що й автори тогочасних літературних творів «засівають зерна» усамостійнення, шукають власну ідентичність. Звідси випливає, що у цих творах містяться ідеї, які ми вважаємо ідеями національної громадянської релігії. Звичайно, такі тези не набули, та й не могли набути, якогось розгорнутого вигляду. Можна заперечити: мовляв, це писали, як правило, люди церковні, які дбали про утвердження своєї церкви. Так, але ж у той час поняття церкви не могло існувати поза національною спільнотою, поза ії прагненнями до утвердження своєї особовості. А тому і почало відроджуватися поняття свята Pусь, як центральне поняття національної віри. До того ж, у зазначений період власне релігійні настанови і настанови національної віри були переплетені, бо не існують одна без одної. Крім того, постаті, про які йтиметься, - це корифеї нашого духу, творіння яких не можна «втиснути» у прокрустове ложе.

Видатною подією того часу був вихід у світ у 1581 р. Острозької Біблії. Сама поява цього твору свідчила про прагнення суспільності до незалежності, до звільнення від влади чужинців. Таким чином, все це дає нам підстави вважати, що у писаннях тих, хто готував це видання, можна віднайти ідеї національної громадянської віри, а тому пильніше придивимося до змісту Поеми і передостанньої поетичної 
Передмови, які передують тексту Біблії і які, як вважають дослідники, належать Герасиму Смотрицькому - видатному українському письменнику-полемісту, поету, педагогу, ученому.

Поема і Передмови мають неоднакове смислове навантаження, хоча підпорядковані одній меті - прославити богообраного князя Острога Костянтина. У першому творі князь зображується в світлі християнського бачення світу, чим підкреслюється його вселенська роль, а у другому - впритул до контексту нашої історії, завдяки чому відтіняється його велич у ній. Але і у Поемі і у Передмовах ми натрапляємо на ідеї, які можна витлумачити як такі, що належать до сфери національної релігії.

Спочатку йдеться про мужнього рицаря, який здолав змія давнього ворога людського роду. Костянтин подібний до першого вояка, але відрізняється своєю зброєю: «Бо держачи в правиці гострий меч двосічний // яким сильні одержують побіду проти ворогів, // рубай, Костянтине, морок ідольської обмани, // бо хоче Бог, щоб всі люди спаслись. // I проганяй еретиків нищівні полки, // бо прийшли вони у світ, як безпощадні вовки» $[8,5]$.

Отже, якщо Юрій Переможець виступає за утвердження добра, то князь $є$ уособленням боротьби проти ідольської омани і єретиків, для того, щоб врятувати людство, бо так хоче Бог. Звідси випливає, що його діяльність є богоугодною, а отже, приділеною. За задумом автора, здолання ворогів передбачає спасіння всіх людей, а тому князь Острозький вивищується над «озброєним рицарем».

Важливим є завершення другої частини Поеми: «Хто згори не нащеплений, той буде викорінений!» $[8,5]$. Вважаємо, що тут в імпліцитному плані наявна така думка: згори «нащеплені» не єретики, а руський народ, а тому він нездоланний.

У третій частині твору князь постає адептом і оборонцем правдивої Христової віри. Спочатку він уподібнюється трьом перським царям, які йшли поклонитися «царю над царями»: його зоря теж іде за цим царем заради спасіння людства. Костянтин непохитно утверджує вчення, що Христос «зі старої людини створив ... нову». I подібно до того, як у «Слові про закон і благодать» митрополита Іларіона князь Володимир уподібнюється Костянтину, таких самих рис набуває і князь Острозький, але в похвальне слово вже вноситься і соціальний момент: «І ти знак хреста недаремно носиш, // ним великому Костянтину ти себе подібним робиш. // Бо він, побачивши його на небі, побідив ворогів, // ти ж побіджуй єре- 
тичних і бісівських начальників» $[8,5]$.

3 наведеного робимо висновок, що у Поемі князь Острозький зображується у вселенському масштабі боротьби з єретиками, зберіганням правдивості християнства, а тому «зоря твоя йде за тим же царем [Христом. - Aвm.], // бажаючи зробити всіх жителями раю». І це уподібнює його до великого Костянтина. У побажанні долати «начальників» натрапляємо на прагнення звільнитися від чужоземного ярма. Немає підстав заперечувати наявність тут ідей громадянської релігії.

Передостання Передмова логічно продовжує Поему. Оскільки князь під орудою Бога діє для спасіння всіх людей, то саме через його діяльність буде спасений і руський народ: «Бог же поклав у серце благовірного князя, // щоб через нього показати нам ... спасенні стежки Східньої Церкви в руськім народі, // Якої ясність сяє серед поганської незгоди» $[9,14]$.

В тексті оспівується православний рід, бо його благословив Бог, а тому в його домі ніколи не зникнуть ні слава, ні багатство. Потім автор Передмови, що дуже важливо для нашого дослідження, переходить до встановлення наступності між київськими князями $і$ князем Острога. Якщо Великий Володимир народ «хрещенням просвітив», а також просвітив всю Руську землю побожністю віри, то Костянтина Бог обрав вірним охоронцем прабатьківської православної віри, а тому в ній з'явилися божественні дари - писання.

Г.Смотрицький вибудовує таку наступність заслуг князів перед Руською землею: «Адже Володимир свій народ хрещенням просвітив, // А Костянтин богорозумними писаннями освітив. // Тоді зникла многобожність ідольської омани, // Сьогодні ж прославляється божество єдиної влади. // Ярослав церковними будовами Київ та Чернігів прикрасив, // А Костянтин єдину соборну церкву писаннями прославив» $[9,14]$.

Отже, Г.Смотрицького можна вважати одним із перших творців національної громадянської релігії на теренах України, що виявилося в наступному: князь Костянтин веде боротьбу за правдивість віри і спасіння всіх людей; завдяки діяльності князя буде спасений і руський народ, і саме князя Бог обрав як вірного сторожа прабатьківської православної віри; руський православний рід $\epsilon$ благословенним, а тому й невигубним; у заклику до єдності православних «всякого сану» князь Острозький є продовжувачем праведних діл київських князів Володимира і Ярослава, чим стверджу- 
ється непохитність і нездоланність святої Руської землі.

Останню тезу Г.Смотрицький своєрідно розвинув у творі «Ключ царства небесного», присвяченого княжичу Олександру. Пояснюючи останньому, що благословення і ласку Божу мають ті, у батьківщині яких не панують чужинці, він пише: «Таким благословенням пошанував та наділив Бог того великого Володимира, який преславно й вельми чудово хрестив Руську землю, чесна лінія церкви та роду його й донині не перервалася. У ній, бо, справдешній наслідник і властивий нащадок, є ваша княжа милість, що на місці отих великосановних та вельми славних предків своїх заступає» [7, 68].

Отже, у писаннях Г.Смотрицького зображується князь Костянтин і його дім, православний руський рід тощо, але не йдеться про релігійні виміри української (руської) державності. Водночас в його уявленнях про благословеність Руської землі, яка розумілася i як держава, відчувається прагнення мислителя крізь призму священного бачити діяльність князя як наступника своїх попередників, бо ж «... польська хроніка і руський літописець свідчать про дім цей, що він побідоносець» [9, 14]. Тож: «Хай дім цей благословенним буде на численні літа, // I слава його хай не зменшиться до кінця світу» [9, 15].

До сказаного вище можна додати певне заперечення: мовляв, виклад свідчить ні про що інше, як про історіософську концепцію автора, в якій поєднуються середньовічні концепції з ренесансними підходами, з мотивами біблійними тощо. Таке заперечення можливе, але певною мірою, а саме, тією мірою, яка, власне, і виступає «маркером» історіософської концепції. Коли ж йдеться про благословеність руської землі, про невигубність руського роду та ін., то мається на увазі становлення на теренах України ідей громадянської релігї.

Подібні ідеї національної громадянської релігії зустрічаються i у творах інших мислителів початку XVII ст. Так, у «Протестації» (1621 р.). козаки постають не тільки славними нащадками княжих часів, а й звитяжниками, відповідно до канонів громадянської релігії це розглядається як певна і тільки їм призначена місія. «І воїстину християнству поневоленому на всьому світі ніхто після Бога добродійства такого великого не виказує, як греки надійністю своїх окупів, король іспанський потужністю свого флоту і військо Запорозьке своєю мужністю і своїми перемогами. Що інші народи, словом і бесідами виборюють, то козаки ділом самим доводять» [1, 
510]. Отже, автори твору розглядають подвижництво козаків, «рицарів Христових» не тільки у вузьких етнічних рамках, а й набагато ширше - у контексті християнської ойкумени.

До речі, дослідники вказують на те, що у цей час у політичній публіцистиці переважали посилання на авторитет православної традиції, на звернення за аргументами до історичних фактів давньоруських часів. «Одночасно, - стверджує П. Сас, - витворювався новий загальноруський авторитет-символ: міфологізованим героєм політичної наррації стають українські козаки» [6, 487]. I це так, коли йдеться про творення національних міфів. Коли ж мовиться про постання національної громадянської релігії, то тут на передній план виходять ідеї, що козаками «Господь Бог керує.., котрий сам відає, на що сі останки тої старої Русі зберігає...» і самі «вони природний розум і од Бога даровану кмітливість мають» і не треба думати «нібито вони є простаками...», вони ж бо з насіння Яфетового...» $[1,510]$. У такий спосіб формується одна 3 основних ідей громадянської релігії - козаки є захисниками святої руської землі, якими керує Господь Бог, і які діють під Божим покровительством.

Сформований у «Протестації» образ козаків червоною ниткою проходить крізь всю історію української громадянської релігії, важливими екзистенціалами якої є споконвічність, одвічність, віковічність, прадавність ... Майже через століття у Конституції Пилипа Орлика уявлення про козаків екстраполюється на весь руський народ і його історію, і ця спільнота означується як «прадавній козацький народ». У вступі читаємо: «Бог ... забажав, змилувавшись, щоби козацький народ відновив свою минулу незалежність, скинувши осоружне уже польське ярмо» [10, 260].

На початку XVII ст. відновлюються (чи постають у новому ракурсі) й інші ідеї національної громадянської релігії. Так, у «Совітуванні о благочестіи» (1621р.) популяризується легенда про навіщення Києва апостолом Андрієм, що «на київських горах ноги його стали, і Росію очі його бачили, і уста благословили, і сім'я віри він у нас посіяв». А тому необхідно влаштовувати урочистості в його честь і дбати про цю традицію, аби нагадати, «що дійсно Русь нічим не менша від інших східних народів, бо мала свого апостола-проповідника». Очевидно, що автор прагнув не тільки показати історичне місце Русі серед східних народів, а й протиставити католикам, котрі хизувалися своєю традицією, яку вони виводили від Петра і Павла, заступництво і благословення першого 
апостола, «першого архієпископа константинопольського і патріарха вселенського» [Цит. за: 2, 213 ].

Проблемі релігійного освячення руської традиції великого значення надавав Захарія Копистенський - визначний український релігійний православний діяч, письменник, автор декількох оригінальних творів так званої полемічної літератури і, передусім, «Палінодії» [4].

У контексті нашого дослідження важливим $\epsilon$ зауваження М.Грушевського про те, що у третій книзі «Палінодії» 3.Копистенського «досить грунтовно для свого часу й обставин і ефектно представлений образ спеціального Божого промислу про руську церкву і Руську державу як іiї патрона» [2, 214]. Дійсно, автор «Палінодії» настійно проводить думку про освячення Руської землі як вияву Божого промислу, що хрещення Русі співвимірне з чудом. Володимир, прозрівши, Руську землю привів до пізнання правдивого Бога, до її хрещення. I далі - надзвичайний пасаж: якщо прозрів Володимир і охрестив Руську землю, тобто Руську державу, то нині церква, яка прозріла, збереже Руську землю. «А тепер прозрела церков, - читаємо у Копистенського, - которая душезбавенною своєю наукою и збавенних таемниц обхоженєм в вере познания правдивого Бога всю окрещенную в ней Рускую землю задержует» [Цит. за: 2, 66].

3 наведеного можна зробити сміливе припущення: якщо у догідних умовах Руська держава опікувалася церквою, то в обставинах, коли держава ще не відродилася, то легітимна церква через правдиву віру утримуватиме єдність і міць Руської землі. Якщо це так, то одне 3 положень української етнічної релігії є: згідно з промислом Божим Руська держава опікується церквою, і церква береже силу і єдність руського національного організму.

Відмітимо й те, що 3.Копистенський дещо своєрідно тлумачить легенду про апостола Андрія, чим намагається обгрунтувати зв’язок Єрусалима і Києва. У похвалі Єрусалиму, що міститься у передмові до «Бесід на Діяння» і має антиримське спрямування, стверджується, що саме у цьому місті постала правдива апостольська церква, а тому єрусалимська церква є матір'ю усіх православних церков. Саме з Срусалима апостоли почали проповідувати Христові догмати, і Бог благословив, аби «світ святого Свангелія» і до Русі дійшов. «То Андрій, первозванний апостол, Божим умислом, Духом святим ведений, прийшов сюди до столичного міста Київського, благословив i, прорікши, що тут віра християнська во- 
зсіяє, помоливсь, - читаємо далі у творі, - аби то збулось, і так збулось» [Цит. за: 2, 74] і за часів Володимира просвітилася Русь.

Аналізуючи цей твір, М.Грушевський зауважує, що тут ми бачимо «обгрунтування нового зв'язку київської церкви з Єрусалимом, першим осідком християнства, - слава Києва як другого Єрусалима християнського Сходу» [2, 214]. Отже, ще одна теза національної громадянської релігії: Київ - другий Єрусалим.

Впадає а око певна модифікація інтерпретацій легенди про апостола Андрія в історії нашої національної віри. Так, якщо у Нестора і в творах інших мислителів ця легенда служила, передусім, утвердженню легітимності християнства в Русі і легітимності святості Русі, то згодом, в умовах бездержав'я, за допомогою цієї легенди стверджується рівність Русі серед інших народів і виникає думка про доконечність самостійності Русі. Уявлення про Київ як другий Єрусалим підігрівало національну гордість: Київ ставав рівнорядним з Новим Римом серед східного християнства і оскільки істинне Христове вчення могло прийти тільки з Єрусалима, то ставилася під сумнів першорядність Риму, спроби католицьких урядових кіл світоглядно та ідеологічно мотивувати своє владарювання на руських землях. I якщо наша інтерпретація правильна, то окреслені громадянські і релігійні ідеї сприяли тому, що серед суспільності утверджувалися ідеї богоосвяченості і благословенності Русі.

I хоча ці та інші ідеї не стверджувалися повсякчасно, але вони жили в суспільності, сприяли розумінню нею своїх особливих потреб та інтересів, гуртували спільноту для їх реалізації. А тому звернення до історичного минулого, до історії відносин з різними народами, хоча і в специфічній формі, але сприяло тому, скажемо словами В. Нічик, що український народ глибше усвідомлював себе єдиним, цілісним суб'єктом світової історії. «Свідомість своєї особливої причетності до неї, що знайшла відображення вже в письмових пам'ятках доби Києво-Руської держави, зокрема в «Повісті врем'яних літ», Київському, Галицько-Волинському та наступних літописах, наприкінці XVI й на початку XVII сторіч знову пробуджується, відроджується й набуває драматичної напруженості. Це зумовлювалося тим, - що у цей час українському народові доводилося відстоювати саме право на своє етнічне існування, на самостійний і незалежний культурно-національний розвиток. Це право не могла дати й захистити будь-яка інша держава, ні польська, ні згодом московська, які вели колонізаційну, асиміляторську 
політику щодо українців, передусім їхньої верхівки» [5, 101-102].

Отже, доба культурно-національного відродження (друга половина XVI - перша половина XVII ст.) характеризується наростанням тенденцій до національного усамостійнення, до пошуку руською спільнотою свого місця у світовій історії, а отже, і до утвердження своєї особовості. Ці тенденції свідчили про перелом у розвитку української культури, що був підпертий потугами козаччини, яка стала новою рушійною силою суспільно-культурного поступу до державної незалежності.

Такі обставини сприятливо вплинули на формування ідей національної громадянської релігії, що відбилися у творах Г. Смотрицького, 3.Копистенського, авторів «Протестації», «Совітування о благочестіи». Її головниі концепти такі: руський православний рід $\epsilon$ благословенним, а тому свята Руська земля $є$ нездоланною; провідники Русі діють за установленнями Бога; приділенність козацької спільноти у захисті правдивого християнства; Русь перебуває під покровительством першого апостола, а тому вона не гірша інші народи, а посідає особливе місце у християнському світі; Київ другий Єрусалим.

\section{ЛІТЕРАТУРА}

1. Борецький Йов та інші. Протестація 1621 р. // Українська суспільнополітична думка. Переклади текстів XV - XVII ст. У 9 тт. - К., 2001. T.2. - C.503-511.

2. Грушевський М. Історія української літератури: В 6 тт., 9 кн. / Упоряд. В.В.Яременко. - К., 1996. - Т.6, кн.1: Літературний і культурнонаціональний рух першої половини XVII ст. -332 с.

3. Ісаєвич Я. Загальна характеристика періоду // Історія української культури. У 5 тт. Т. 2. Українська культура XIII - першої половини XVII. - K., 2001. - C.479-484.

4. Копистенський 3. Палінодія // Українська література XVII століття. K., 1987. - C.10-21.

5. Нічик В. Петро Могила в духовній історії України. - К., 1997. - 328 с.

6. Сас П. Політична культура суспільства // Історія української культури. В 5 тт. Т. 2. Українська культура XIII - першої половини XVII. - К., 2001. - C.484-491.

7. Смотрицький Г. Ключ царства небесного // Українська суспільнополітична думка. Переклади текстів XV-XVII ст. У 9 тт. - К., 2001. - 
T.2. - C. $68-70$.

8. Смотрицький Г. Поема // Острозька Біблія. - Львів, 2006. - С.5.

9. Смотрицький Г. Передмова // Острозька Біблія. - Львів, 2006. - С. 14-15.

10. «Уклад прав і вольностей» // «Пакти і Конституції» Української козацької держави. - Львів, 2011. - 440 с.

Зінкевич Т. Ідеї начіональної громадянської релігії у творах діячів українського культурного відродження кіния XVI - початку XVII cm.

У статті обгрунтовується думка, згідно $з$ якою національна громадянська релігія характерна для спільноти, яка виборює свою державність. За таких умов феномен, що розглядається, постає як сакральний вимір прагнення нації до відновлення, утвердження державності, сприйняття спільнотою своєї дієвості як наперед визначеної, а суспільство як таке, у якому певні соціально-політичні настанови специфічно переплітаються 3 релігійними міфами, легендами, обрядами, практиками. Громадянська релігія бере свій початок у потребі спільноти знаходити сакральне у трансцендентній дії, яка укорінена в історію територій. Доводиться, що основні концепти національної громадянської релігії доби культурнонаціонального відродження (друга половина XVI - першої половини XVII ст.) такі: руський православний рід є благословенним, а тому свята Руська земля є нездоланною; провідники Русі діють за установленнями Бога; Київ - другий Срусалим.

Ключові слова: громадянська релігія; Срусалим; Київ; національна громадянська релігія; правдиве християнство; руський православний рід; свята Руська земля.

Зинкевич Т. «Идеи национальной гражданской религии в произведениях деятелей украинского культурного возрождения конца XVI- начала XVII в.».

В статье обосновывается мысль, согласно которой национальная гражданская религия характерна для общности, борющейся за свою государственность. При таких условиях рассматриваемый феномен предстает как сакральное выражение стремления нации к возрождению и утверждению государственности, восприятие общностью своей действенности как предопределенной, а общество - как такое, в котором определенные социально-политические установки специфически переплетаются с религиозными мифами, легендами, обрядами, практиками. Гражданская религия берет свое начало в потребности общности отыскивать сакральное в трансцендентном, извечно-линейном действии, которое коренится в истории территорий. Доказывается, что основные концепты национальной гражданской религии эпохи культурно-национального возрождения (вторая половина XVI - первая половина XVII в.) таковы: руський православный род является благословенным, а поэтому святая Русь неодолима; кормчие

188 ISSN2078-8142 Мультиверсум. Філософський альманах.-2016.-Випуск 3-4(151-152) 
Руси действуют по установлениям Бога; Киев - второй Иерусалим.

Ключевые слова: гражданская религия; Иерусалим; Киев; национальная гражданская религия; правдивое христианство; православный род Руси; святая Русь.

Zinkevych T. The Ideas of National Public Religion in the Works of Ukrainian Cultural Renaissance Figures (the End of XVI - the Beginning of XVII century).

The article substantiates the argument that the national civil religion characteristic of a community that struggles statehood. Under these conditions, the underlying phenomenon appears as a sacred dimension aspirations of the nation to recovery and strengthening of statehood, community perceptions of their effectiveness as given in which certain socio-political guidelines specifically intertwined with religious myths, legends, rituals, practices. Civil religion has its roots in the community need to find a sacred transcendent eternitylinear action that is rooted in the history of the area. The article presents basic concepts of national public religion of defined period, such as Rus orthodox kindred is blessed and that is why Holy Rus land is insuperable; Rus preachers act on the instruction of God; the significance of the Cossack community in the protection of true Christianity; Rus is being under the protection of the first apostle and that is why it takes the special place in the Christian world; Kyiv is the second Jerusalem.

Key words: public religion, national public religion, Holy Rus land; Rus orthodox kindred, Kyiv, Jerusalem, true Christianity. 